\title{
Biomass assessment in annelids: A photogrammetric method suitable for hatchlings and adults developed for Eisenia andrei
}

Determinación de biomasa en anélidos: Método fotogramétrico utilizable en neonatos y adultos desarrollado en Eisenia andrei

Determinação de biomassa em anelídios: Método fotogramétrico desenvolvido para Eisenia andrei adequado para neonatos e adultos

\section{AUTHORS}

\section{Ortega Hidalgo M. \\ M. ${ }^{\circledR}$}

mercedes.ortega@

ehu.es

\section{Iparraguirre \\ Bolaños E.}

Brea San-Nicolás C.

@ Corresponding Author

Departamento de Genética, Antropología

Física y Fisiología Animal,

Facultad de Ciencia y

Tecnología, Universidad

del País Vasco. Apdo.

644. 48080 Bilbao, Spain.
Received:24.11.2015 | Revised: 17.01.2016 | Accepted:27.01.2016

\section{ABSTRACT}

A simple photogrammetric, non-destructive method for measuring individual biomass in tubular soft-bodied organisms has been developed using Eisenia andrei. Photographic procedures can be easily performed with low cost digital cameras and the number of pictures to be processed can be reduced to two per animal (Variation Coefficient $\leq 3.5 \%$ ) even at sizes $\sim 10 \mathrm{mg}$ live weight. Image analysis was undertaken using CobCal 2.0(C) software. No bias was induced by body position. Accuracy in terms of the regression coefficient of the equation $\left(y=\mathrm{a}^{*} x^{\mathrm{b}}\right)$ relating portrayed area $\left(\mathrm{mm}^{2}\right)$ to live weight (mg) was $98 \%$. Two different procedures were designed for laboratory and field uses. No differences between methods appeared at sizes over eight $\mathrm{mg}$ live weight, resulting in a common function relating image area to live weight results $\left(\mathrm{PS}=3.27^{*} \mathrm{LW}^{0.681}\right)$. Below $8 \mathrm{mg}$, the weight exponent remained unchanged but the value for the elevation rose to 4.21 indicating an increase of surface exposure to the camera lens in newly-hatched worms: the visible part of the geometric area (cylinder shape) enlarged from $34 \%$ to $43.52 \%$. As a conclusion this non-invasive procedure proved suitable for worms ranging from sizes of 0.2 to $3000 \mathrm{mg}$ live weight to determine biometric parameters such as length, volume, surface or body weight, which are key factors for interpreting physiological responses underlying growth patterns.

\section{RESUMEN}

En este trabajo se ha desarrollado, utilizando la especie Eisenia andrei, un método no invasivo de estimación de medidas de biomasa en organismos tubulares basado en técnicas fotográficas. Las fotografías de los animales se pueden obtener con cámaras digitales de bajo coste y el numero de fotografias que deben ser tomadas por individuo puede reducirse a dos (Coeficiente de Variación 3.5\%) incluso en individuos recién nacidos ( 10 mg). Para el análisis de imagen se utilizó el programa CobCal 2.0@. La relación entre la superficie fotografiada (PS) y el peso vivo $(L W)$ fue independiente de la posición del animal y se obturv una ecuación con una varianza explicada del 98\%. Se desarrollaron dos métodos de toma de fotografías (laboratorio y campo) y, al no encontrarse diferencias en individuos de talla superior a $8 \mathrm{mg}$, se estableció una función común que relacionaba el área de la foto con el peso vivo $\left(P S=3.27^{*} L W^{0.681}\right)$. Por debajo de $8 \mathrm{mg}$, el exponente del peso se mantuvo pero el valor del coeficiente aumentó a 4,21, indicando un incremento en la superficie expuesta a la cámara en individuos recién nacidos: el área visible en relación a la superficie total (considerando un cuerpo cilindrico) aumentó de 34\% a 43,52\%. Como conclusión, se demostró que este método no invasivo puede ser empleado en individuos entre 0,2 a $3000 \mathrm{mg}$ de peso vivo, para determinar parámetros biométricos como la longitud, el volumen, la superficie o el peso vivo, que son factores clave para interpretar las respuestas fisiológicas subyacentes a los patrones de crecimiento. 


\begin{abstract}
RESUMO
Desenvolveu-se um método simples, não destrutivo, baseado em técnicas fotogramétricas, para medir a biomassa individual de organismos tubulares de corpo mole, utilizando a espécie Eisenia andrei. As fotografias podem ser obtidas facilmente com câmaras fotográficas de baixo custo, podendo o número de fotografias a serem processadas ser reduzido a dois por animal (Coeficiente de Variação $\leq 3,5 \%$ ) mesmo em individuos com massa viva $10 \mathrm{mg}$. Para a análise de imagem utilizou-se o programa CobCal 2.0@. A relação entre a superfície fotografada (PS) e a massa viva $(L W)$ foi independente da posição do animal, obtendo-se uma equação com uma variância explicada de 98\%. Foram desenvolvidos procedimentos diferentes para uso laboratorial e de campo, os quais não apresentaram diferenças em individuos de massa superior a $8 \mathrm{mg}$ permitindo o estabelecimento de uma função comum que relaciona a área da imagem com a massa viva do animal $\left(P S=3,27^{*} \mathrm{~L} W^{0.681}\right)$. Para um valor de massa inferior a $8 \mathrm{mg} 0$ expoente da massa mantem-se inalterado mas o valor do coeficiente subiu para 4,21 indicando um aumento da superfície exposta à camara em individuos recém-nascidos: a área visivel em relação à superfície total (considerando um corpo cilíndrico) aumentou de 34 a 43,52\%. Como conclusão, demonstrou-se que este método não invasivo pode ser usado em indivíduos com massa viva entre 0,2 e $3000 \mathrm{mg}$ para determinar parâmetros biométricos tais como 0 comprimento, volume, área ou mass a corporal, os quais são fatores chave para a interpretação de respostas fisiológicas subjacentes a padröes de crescimento.
\end{abstract}

\section{Introduction}

The utilization of non-disturbing sampling techniques that would provide a permanent historic record of photo-samples has been long encouraged in the context of surveys of conservation status particularly as regards to populations of marine benthic organisms (Littler and Littler 1985; Ponder et al. 2002). More recently, developments in software and imaging technology have supplied easily managed and inexpensive tools that provide accurate and repeatable measures that have extended the scope of photogrammetric methods to quantitative field studies of biomass evolution and growth rates in aquatic invertebrates (Bernardini et al. 2000; Vanaverbeke et al. 2003; Page et al. 2005; Abdo et al. 2006). Advantages of these methods in the context of growth studies include the possibility of accessing early stages of the life cycle, minimizing damage associated with frequent handling, allowing simultaneous recording of different biometric parameters and providing the means for long-term individual registers of biomass in order to study population dynamics. Concerning terrestrial invertebrates, Perea et al. (2008) applied it to evaluate growth in small juveniles of Cantareus aspersus (Müller 1774) snails. In this work undertaken with Eisenia andrei (Bouché 1972), our objective has been to standardize conditions leading to obtaining reliable quantification of individual biomass, length, surface, volume, and hydration level for long-term surveys of tubular soft-bodied organisms by means of photogrammetric techniques. For this purpose, we have established the minimum number of images to be taken in order to obtain area measurements, evaluated accuracy and precision in laboratory conditions and explored the effectiveness under field conditions.

\section{KEYWORDS \\ Earthworm growth,}

morphometrics, image analysis, individual weight evolution.

PALABRAS

CLAVE

Crecimiento de gusanos de tierra, morfometría, análisis de imagen, evolución

de crecimiento individual.

\section{PALAVRAS-}

CHAVE

Crescimento de minhocas, morfometria, análise de imagem, evolução da massa individual. 


\section{Materials and methods}

\subsection{Biological material and maintenance condition}

Specimens of Eisenia andrei used in this experiments were reared in captivity and maintained in darkness in a growth chamber under controlled conditions of temperature $\left(20 \pm 2^{\circ} \mathrm{C}\right)$ and humidity $(80 \pm 3 \% \mathrm{RH})$. Annelids were fed with horse manure $(70.1 \%$ organic matter, $\mathrm{pH}=7.413 \pm 0.023$ ) collected from horses maintained in an Atlantic meadow under semi extensive conditions.

\subsection{Weight determinations}

Live and dry weights (LW and DW) of worms used in the experiments were obtained using a Sartorius micro@ digital analytical balance (readability: $0.0001 \mathrm{mg}$ ). Prior to live weight determinations, animals were carefully cleaned according to the following procedure: short immersion in a small Petri dish containing deionized water and drying with a moist cloth, verifying no injuries had been incurred and removing any external traces of water.

In order to obtain data for individual biomass of worms excluding gut content, a batch of 99 worms (from 1.7 to $648.6 \mathrm{mg} \mathrm{LW}$ ) were divided into two groups of similar size distribution. In one group, currently fed animals $(n=50)$ were weighed before (Live Weight) and after (Dry Weight) standard procedures of dehydration (24 hours oven drying at $80^{\circ} \mathrm{C}$ ). In the other group, animals were fasted for 48 hours (gut voided) and both live and dry weight determined similarly.

\subsection{Photogrammetric method}

Photographs were taken with a Kodak@ Easyshare M763 digital camera (focal length equivalent 34 to $102 \mathrm{~mm}$; optical sensor size 5.744; maximum aperture F2.8-F5.1). In order to favour simplicity in data acquisition, camera parameters were fixed preferentially in the automatic mode: sensor resolution 7MP (3072 x 2304); light sensitivity: ISO auto (64-320); exposure metering: multi-segment; shutter speed: automatic (from 4 to $1 / 1400 \mathrm{sec}$ ); optical zoom 3X; macro focus range from 10 to $70 \mathrm{~cm}$; focus adjustment: autofocus multi-area; focal distance: $25 \mathrm{~cm}$ (tripod).

Animals were placed in Petri dishes with a graduated reference (a grid: $4 \mathrm{~mm}^{2}$ per square). Dishes of different diameters adjusted to worm size were required (Figure 1).

Two photograph-taking procedures were used. In the "Field Method" (FM), the grid was situated under the Petri dish, while it was placed aside

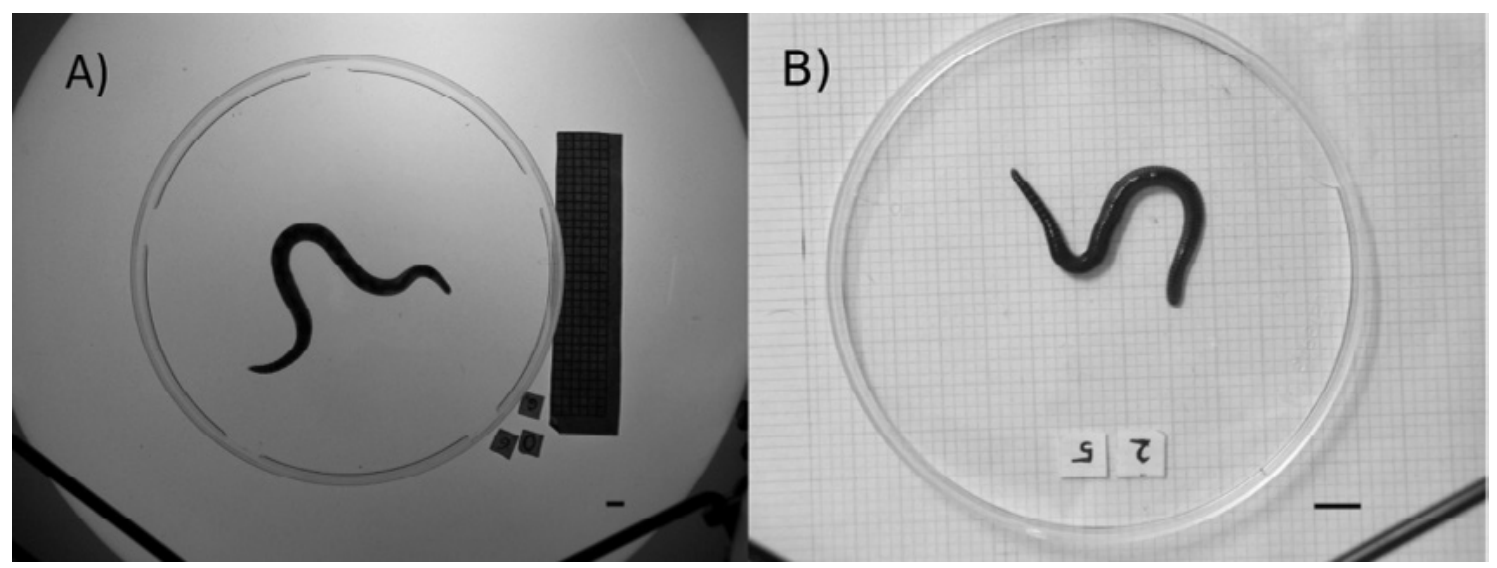

Figure 1. Digital photographs of Eisenia andrei. A: Laboratory Method (LM). Scale bar $=4 \mathrm{~mm}$. B: Field Method (FM). Scale bar $=4 \mathrm{~mm}$. 
in the alternative "Laboratory Method" (LM). Caution was taken in both procedures to keep the ventral surface of every individual in contact with the bottom of the Petri dish.

In the lab method ( $\mathrm{n}=294$; size range $=$ 0.2 - $3132.0 \mathrm{mg} \mathrm{LW})$, worms were carefully cleaned from debris prior to taking pictures and illumination was situated underneath the animals (Figure 1A) allowing direct determination of surface displayed in the image. In contrast, in the field method ( $\mathrm{n}=123$; size range = 8.4 - $463.5 \mathrm{mg} \mathrm{LW}$ ) individuals were readily portrayed, either with light situated over the animals or without any artificial illumination (Figure 1B) and photographs required subsequent image treatment with Adobe ${ }^{\circledR}$ Photoshop ${ }^{\circledR}$ to define clear borders.

Digital images were transferred to the computer in JPG format and individually processed using CobCal® 2.0 software in order to calculate the photographic surface (PS). The programme, easily handled, is based on pixelization and colorimetric analysis of images where the selected shape to be measured is encoded as a positive colour and identified against a background (negative colour). Precision is set up by default at the highest level and results are given as a fraction of total delimited area (in our case a circle of adequate diameter).

Since the final objective was transforming surface data into weight figures across a wide size gradient while retaining maximum accuracy at the lower segment of worm population (newly hatched $\leq 0.8 \mathrm{mg}$ live weight), three sources of variability were tested. Initially, the effect of position and body shape and minimum number of images required to attain the least possible inter-pictures variation was evaluated using the FM. Later, differences in feeding and digestive conditions were analyzed by means of the LM.

\subsubsection{Influence of body shape and position on surface determination}

Observation and careful handling of worms led us to standardize 3 positions in which pictures could be taken: fully extended, coiled and intermediate (Figure 2). Since expected error would presumably increase at the lower sizes, 72 individuals ranging from 10.1 to $461.9 \mathrm{mg}$ of LW were selected to obtain details of precision preferentially in smaller animals.

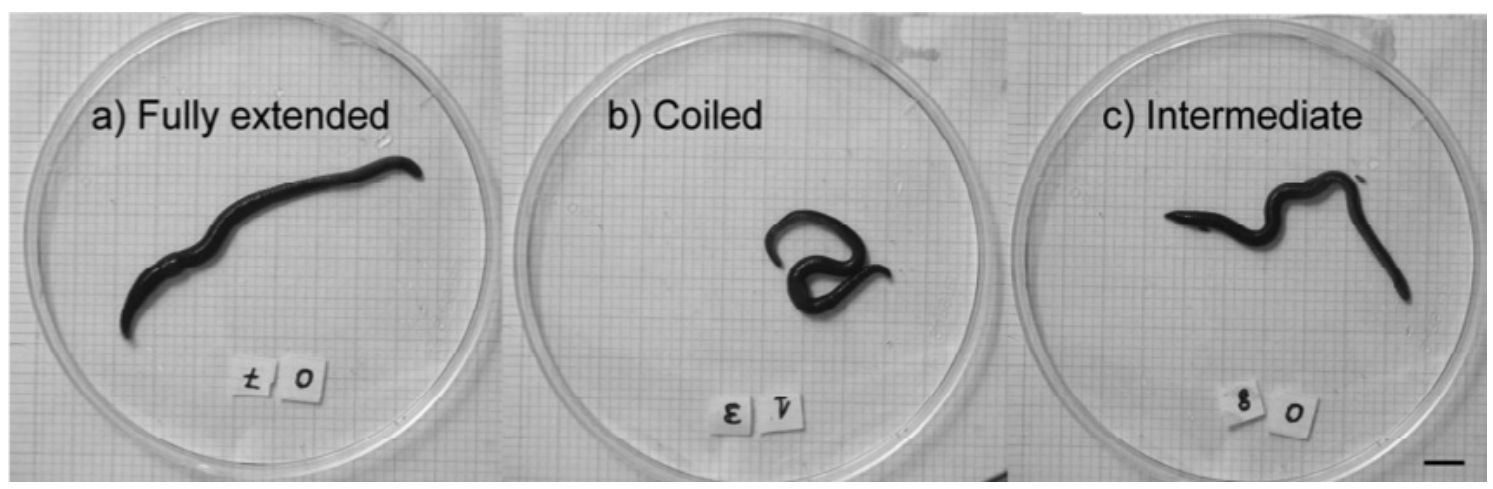

Figure 2. Eisenia andrei images taken in the three standardized positions. Scale bar $=4 \mathrm{~mm}$.

Two different procedures were assayed. A preliminary experiment undertaken with a group of 20 individuals involved photographing single specimens having been forced to adopt the three positions alternatively, and more than one picture was taken in every position in most cases. Later, a broader experiment was performed in which specimens within a group of 72 individuals were repeatedly portrayed (at least 5 pictures per worm to a total of 561 pictures).

\subsubsection{Number of images taken}

A set of 80 individuals (10.1 to $446.7 \mathrm{mg}$ of live weight) was distributed in 7 groups ( $n=10-14)$ according to the number of pictures to be taken: 2, 3, 4, 5, 6, 7 and $>7(8,9,10)$. Size differences within groups were favoured as well as no differences as regards mean LW among groups. Pictures of worms spontaneously appearing as fully extended or in the intermediate position 
were employed. FM conditions pertained to this trial.

Criteria to ascertain least advisable number of pictures to increase precision (lowest variability around the mean) requires some meticulousness. Since size range of worms is maximized and standard deviation increases for larger animals a size independent statistic, the variation coefficient (standard deviation/mean), was chosen.

2.3.3. Influence of feeding conditions on surface determination and weight estimations

Routine rearing of worms precludes knowing the feeding activity of a given organism and in order to test the influence of feeding conditions on both live weight and image based size calculations, 38 individuals were fasted for $48 \mathrm{~h}$ with the live weight registered and pictures taken at daily intervals $(0,24$ and $48 \mathrm{~h})$, the latter according to the LM. Starvation took place in individual chambers with a moist cloth that was kept at saturation and faeces were removed periodically.

2.4. Morphometric determinations by image analysis

A group of 60 worms ranging from 2.3 to $681 \mathrm{mg}$ of live weight were hand sorted from culture vessels and individually photographed and weighed (life weight). Later, they were measured for length $(L=m m)$ and radius $(r=\mathrm{mm})$ with a $0.05 \mathrm{~mm}$ precision digital calliper and volume by immersion determined according to Archimedes principle. Geometric Surface (GS) and Geometric Volume (GV) were computed according to the formula $2 \pi r L$ and $\pi r^{2} L$ respectively.

\subsection{Biomass conversion}

Photographic surface measurements $\left(\mathrm{mm}^{2}\right)$ were related to $L W(\mathrm{mg})$ by means of the equation $Y=a^{*} X^{b}$. Linear regression procedures (after logarithmic $_{10}$ transformation of data) followed by ANCOVA and TUKEY analysis, were used to ascertain significance of differences between both regression coefficients and intercepts.

\section{Results}

\subsection{Biomass determinations}

Scaling of dry to live weight (in $\mathrm{mg}$ ) was undertaken separately in two groups of worms, fed and fasted for $48 \mathrm{~h}$. While in fed worms both live and dry weights included gut contents, in fasted animals two relationships were established: one excluding gut contents in which DW related to final LW (after $48 \mathrm{~h}$ starvation) and one in which entire (initial) LW related to DW. Linear regression equations obtained after loglog transformations are shown in Table 1.

Table 1. Coefficients of Log-Log regression equations of Dry Weight (DW = mg) vs. Live Weight $(\mathrm{LW}=\mathrm{mg})$ of Eisenia andrei. Differences in individual equations for gravimetric measurements in different feeding conditions are analyzed through ANCOVA

\begin{tabular}{lcccccc} 
Condition & $\mathbf{N}$ & $\mathbf{L W}(\mathbf{m g})$ & $\mathbf{D W}(\mathbf{m g})$ & $\mathbf{R}^{2}$ & Intercept $\left(\mathbf{C l}_{95 \%}\right)$ & Slope $\left(\mathbf{C l}_{95 \%}\right)$ \\
\hline Fed & 50 & $10.10-446.70$ & $1.06-50.58$ & 0.996 & $(-0.996) \pm 0.043$ & $1.025 \pm 0.019$ \\
\hline Fasted & 49 & $1.70-648.60$ & $0.28-105.34$ & 0.992 & $(-0.793) \pm 0.055$ & $0.986 \pm 0.025^{a}$ \\
\hline ANCOVA & DF & F-Value & P-Value & & & \\
Slope & 1,94 & 6.168 & 0.0148 Sig. & & & \\
\hline
\end{tabular}

$\mathrm{LW}=$ Live weight; DW = Dry weight; $\mathrm{DF}=$ degrees of freedom; $\mathrm{Cl}_{95 \%}=$ Confidence intervals; ${ }^{\text {aslope }}=1$, Recalculated intercept $=-0.801$. 
LW regression coefficients closely approached unity in both feeding conditions. Nevertheless, high $\mathrm{R}^{2}$ values (over 99\% explanation of actual variability) and sample size resulted in significance differences between slopes:

\section{(F 1) $\quad$ Fed: $\mathrm{DW}=0.1^{*} \mathrm{LW}^{1.025}$}

(F 2) Fasted (both voided):DW $=0.16^{*} \mathrm{LW}^{0.986}$

Assuming an isometric relationship between dry and live weight (see $\mathrm{Cl}_{95 \%}$ for the slopes), flesh DW (mg) with digestive tract full represented 10\% of entire LW (mg) (F1) and the proportion of body water reduced from $90 \%$ in fed animals (F1) to $84.3 \%$ in fasted worms (F2). In this respect, in the subsample set to eliminate intestinal content, LW (mg) changed with starvation, relating to initial weight for Eisenia andrei according to the linear function: Live Weight ${ }_{(48 \mathrm{~h} \mathrm{starved})}=0.8668^{*}$ Initial Live Weight $\left(R^{2}=0.979\right)$, indicating loss of $13.32 \%$ of initial weight irrespective of size.

In order to transform LW data of currently cultured individuals into DW of the carcass, the following relationship relating voided DW (mg) to fed LW (mg) was calculated: Fasted (entire LW) $\mathrm{DW}=0.13^{*} L W^{0.994}\left(\mathrm{R}^{2}=0.989\right.$; $n=50$ ), where DW of the flesh represented $13.5 \%$ of the entire LW. In fact, ANCOVA comparisons between this equation and (F2) resulted in no differences between slopes ( $p=0.6962$ ), which described an isometric relationship while the intercepts remained significantly different $(p<0.001)$.

Mean diameter was $2.98 \mathrm{~mm}( \pm 0.80)$ and $76.67 \%$ of the specimens ranged from 2 to $3.5 \mathrm{~mm}$ with a mean length of $38.51 \mathrm{~mm}$ $( \pm 22.78)$ for a total distribution between 4.5 and $80 \mathrm{~mm}$. Length $(\mathrm{mm})$ increased with size (mg) according to the allometric equation: Length $=0.8921^{*}$ Live Weight ${ }^{0.6683}\left(\mathrm{R}^{2}=0.9028\right.$; $\mathrm{n}=60)$.

Diameter changes along growth showed an isometric pattern presenting a weight exponent of 0.3352 . The combination of patterns exhibited by length and diameter indicated worms become slimmer while length /volume rise.

Since volume and weight are alternative measures to biomass computing, and considering that a cylinder is a good approach to worm shape, we initially tested two procedures to determine volume across a wide range of sizes: geometric calculations based on length parameters determined with a digital calliper and measures of water displaced by immersion. Results were analyzed by linear regression treatments, previous log-log transformation, and presented on Table 2. No statistical differences were evident as regards to both slope and intercept relating volume to $\mathrm{LW}$ and a common regression equation irrespective of method was calculated (Table 2; Figure 3).

Table 2. Coefficients of Log-Log regression equations of Geometric and Immersion Volumes (mm³) vs. Live Weight $(\mathrm{mg})$ in Eisenia andrei. Differences between individual equations are analyzed through ANCOVA

\begin{tabular}{|c|c|c|c|c|c|c|}
\hline Method & $\mathbf{N}$ & LW (mg) & Volume $\left(\mathrm{mm}^{3}\right)$ & $\mathbf{R}^{2}$ & Intercept $\left(\mathrm{Cl}_{95 \%}\right)$ & Slope $\left(\mathrm{Cl}_{95 \%}\right)$ \\
\hline Immersion Volume & 57 & $18.4-471.3$ & $20-500$ & 0.96 & $0.014 \pm 0.111$ & $0.995 \pm 0.057$ \\
\hline Geometric Volume & 57 & $18.4-471.3$ & $21-473$ & 0.96 & $-0.040 \pm 0.119$ & $1.042 \pm 0.061$ \\
\hline ANCOVA & DF & $F$-Value & $P$-Value & Common Values & & \\
\hline Slope & 1,110 & 1.322 & 0.2527 No. Sig & $1.010 \pm 0.041$ & & \\
\hline Intercept & 1,111 & 3.126 & 0.0800 No. Sig & $-0.010 \pm 0.082$ & & \\
\hline
\end{tabular}

$\mathrm{LW}=$ Live weight; $\mathrm{DF}=$ degrees of freedom; $\mathrm{Cl}_{95 \%}=$ Confidence intervals. 


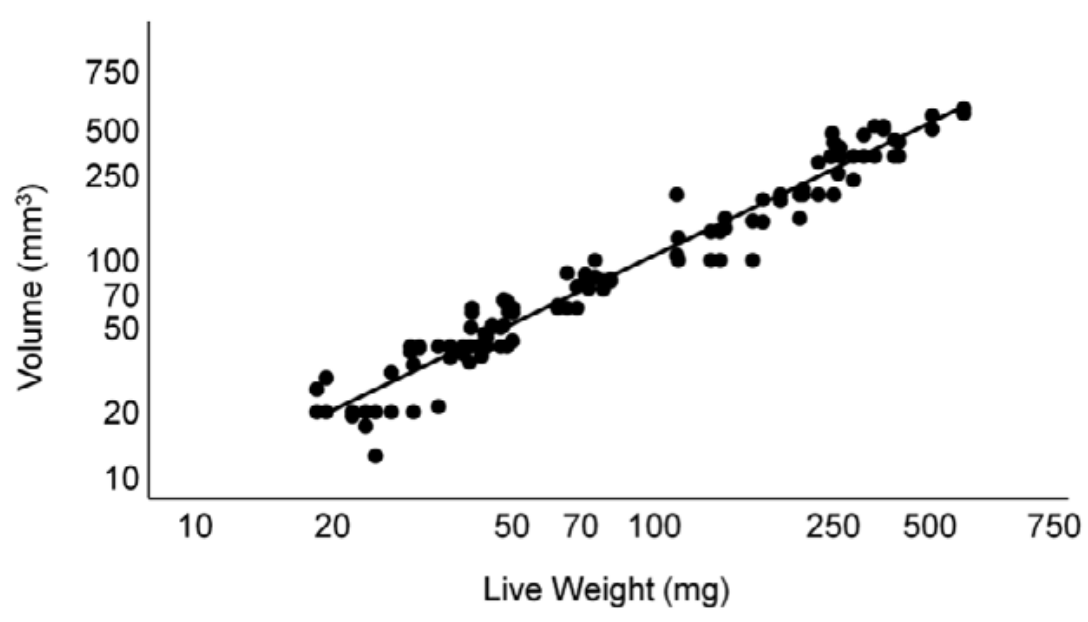

Figure 3. Volume $\left(\mathrm{mm}^{3}\right)$ vs. Live Weight $(\mathrm{LW}=\mathrm{mg})$ in Eisenia andrei: Volume $=0.98^{*} \mathrm{LW}^{1.01}\left(\mathrm{R}^{2}=0.96 ; \mathrm{n}=114\right)$.

Confidence intervals indicated $y=x$ (i.e. volume $=\mathrm{LW}$ ) since slope and intercept were not significantly different from unity and zero respectively. As a consequence, density calculations reproduced water figures: LW: $1 \mathrm{mg}$; Volume: $0.98 \mathrm{ml}$; Density $=1 / 0.98=1.02 \approx 1 \mathrm{mg} / \mathrm{ml}$. This result agrees with the determinations of water content of worms explained above.

Surface to Volume ratio $\left(\mathrm{S} / \mathrm{V}=\mathrm{mm}^{2} \mathrm{~cm}^{-3}\right)$ declined along with LW (mg) increasing according to the equation: $\mathrm{S} / \mathrm{V}=10.7^{*}$ Live weight ${ }^{-0.32}\left(\mathrm{R}^{2}=0.9\right)$, lowering by a factor of 3 between 18 and $472 \mathrm{mg}$.

\subsection{Photographic Surface (PS)}

\subsubsection{Number of pictures required}

Analysis of precision in PS determination as related to the number of individual pictures taken (from 2 to 10) was tested according to the following procedure: groups of 7 to 14 worms were classified with regard to the number of pictures taken of every individual within the group (from 2 to 10 per worm) and a variation coefficient was calculated for each individual. ANCOVA analysis was performed including LW as covariate and an interaction term for the product of LW and number of pictures taken (Table 3) in order to test the significance of differences among variation coefficients when increased numbers of pictures were considered. No significant differences were evident among the 7 groups and $P$-values largely exceed 0.05 for every factor. A common variation coefficient of 0.06 irrespective of the number of pictures taken was consequently calculated and results for the mean variation coefficients for every group appear in Figure 4.

\subsubsection{Photogrammetric vs. Geometric procedures}

In order to calculate the proportion of total surface portrayed in a picture, photogrammetric measurements of surface were compared with

Table 3. Results of ANCOVA analysis of the variation coefficient, including live weight (mg) as covariate and an interaction term for the product of live weight and number of pictures taken (between 2 and more than 7 pictures)

\begin{tabular}{lcc}
\multicolumn{1}{c}{ ANCOVA } & F-Value & $\boldsymbol{P}$ - Value \\
\hline Number of pictures & 0.370 & 0.8951 No. Sig \\
\hline Live Weight & 1.752 & 0.1903 No. Sig \\
\hline Number of pictures*Live Weight & 0.823 & 0.5565 No. Sig \\
\hline
\end{tabular}




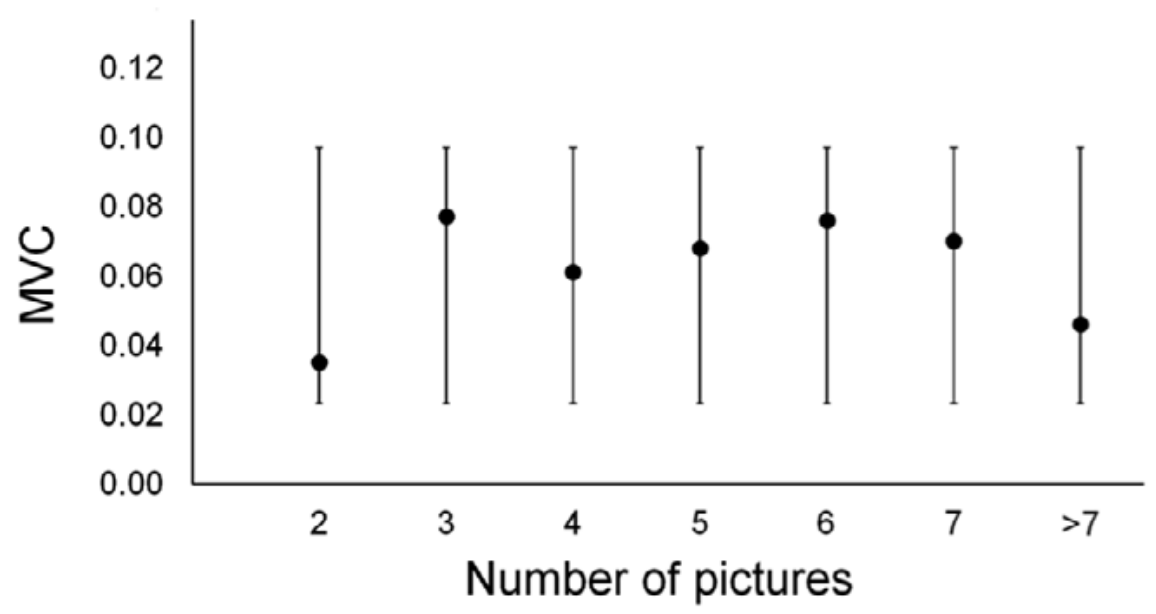

Figure 4. Mean Variation Coefficients (MVC) vs. number of pictures taken per individual. Error bars stand for S.D.

the GS of the cylinder (2mrL) obtained from calliper measurements (Figure 5).

A good correlation coefficient explaining $96 \%$ of variability resulted for the isometric relationship between both sets of data and intercept and slope estimations were highly significant $(P<0.001)$. As a conclusion, the image displayed $34 \%$ of $\mathrm{GS}\left(\mathrm{mm}^{2}\right)$ : $\mathrm{GS}=P S / 0.3404$.

Photogrammetric measurements of surface can also be used to calculate volume as an alternative to the geometric or immersion methods: Volume $=G S^{*} r / 2$, so Volume $=P S^{*} r / 0.6808$.
Volumes so obtained do not differ from geometrical estimations (ANOVA: $P=0.9493$, $\left.F_{1,112}=0.004\right)$.

\subsection{Field method (FM)}

Distribution of size frequencies (LW in $\mathrm{mg}$ ) of the laboratory-cultured batch of Eisenia andrei used in this experiment is shown in Figure 6. Since body size is directly related to age, we selected individuals from different sizes (from $8 \mathrm{mg}$ to $464 \mathrm{mg}$ ) including a variety of growing stages. Two cohorts became evident: newly hatched and non-clitellated juveniles ranging from 8

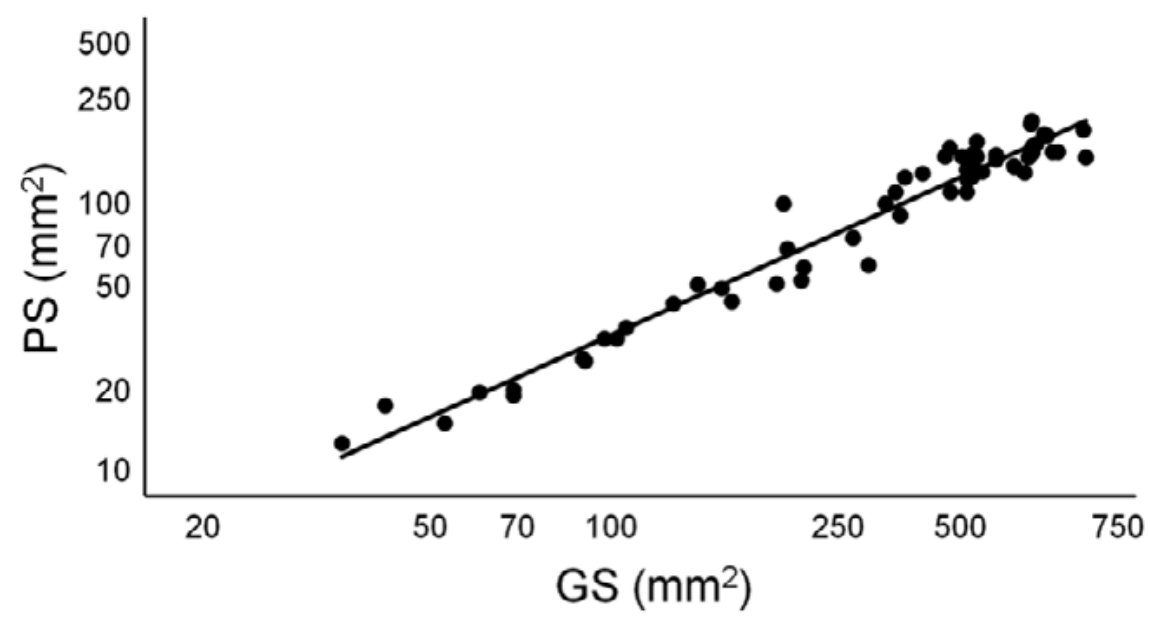

Figure 5. Photographic Surface $\left(P S=m^{2}\right)$ vs. Geometric Surface $\left(G S=m^{2}\right)$ in Eisenia andrei: $P S=0.34^{*} G S{ }^{0.987}\left(R^{2}=\right.$ $0.958 ; n=60) . \mathrm{Cl}_{95 \%}$ is \pm 0.055 for the slope and \pm 0.1062 for the elevation. 
to $110 \mathrm{mg}($ Mean $=45.941 ; \mathrm{SD}=30.324)$ and larger juveniles as well as clitellated and nonclitellated adults with LW from $140 \mathrm{mg}$ to $464 \mathrm{mg}$ (Mean = 293.537; SD = 77.06).
3.4. Analysis of the effects position and body shape

The possible influence of corporal position in the photogrammetric estimations of body surface and its effect on the relation with body weight

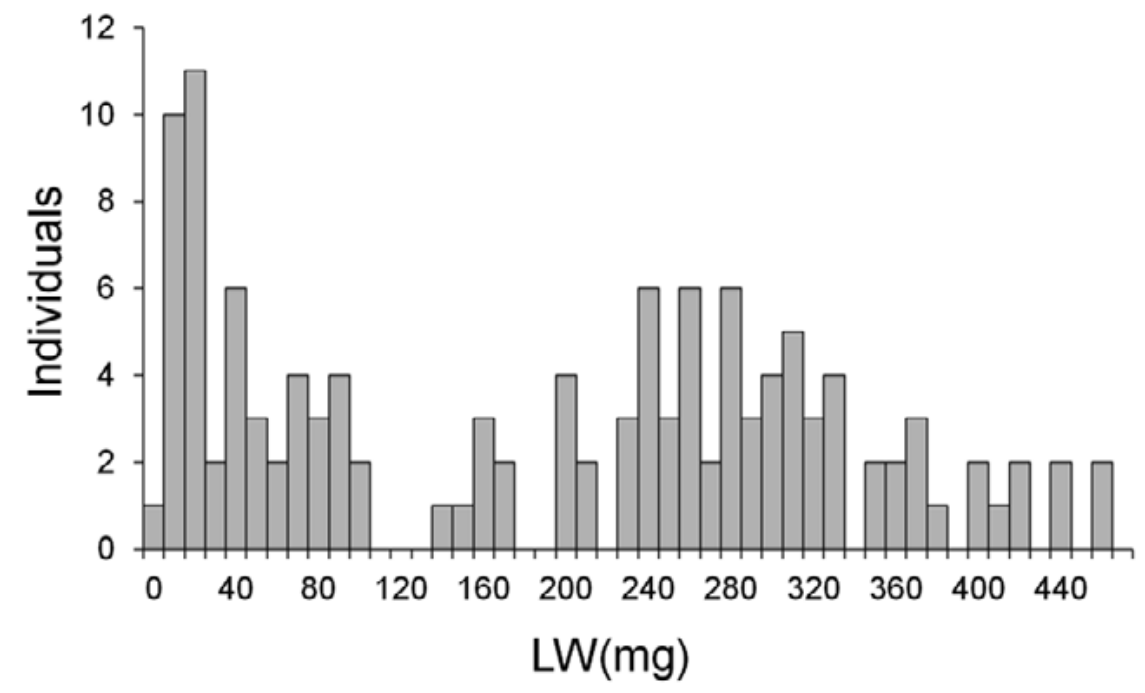

Figure 6. Histogram for the frequency distribution of Live Weight ( $\mathrm{LW}=\mathrm{mg}$ ) of specimens of Eisenia andrei used in the Field Method (FM).

was undertaken in two separate experiments summarized in Table 4. Results from the design in which a given worm $(n=20)$ was alternatively forced to adopt a fully extended, coiled or intermediate position showed no differences in both parameters of the lineal regression equation relating estimations of PS to LW. Consequently, a common function with regression coefficient of $0.676 \pm 0.014$ and intercept of $0.472 \pm 0.029$ explaining $98 \%$ of experimental variation was calculated.

In the next step, where images of 72 specimens within the same range of sizes were recurrently taken, identical results were obtained (Table 4). As a consequence, surface determinations based on digital images had a common relationship with live body weight irrespective of position, body shape or number of pictures taken per individual worm within a size range of 10 to $460 \mathrm{mg}$ of LW. So, all data appearing in Figure 6 $(n=123)$ was pooled in a single equation shown in Figure 7. The equation explained $98 \%$ of variation and coefficients were highly significant $(p<0.001)$.

\subsection{Laboratory Method (LM)}

The frequency distribution of LW (mg) of individuals used in the LM is illustrated in Figure 8. The 294 animals covering the whole range of sizes found in our breeding scheme were analyzed in two separate groups. Newly hatched worms $(n=107)$ less than one day after hatching $\left(\mathrm{LM}_{\mathrm{NH}}<8 \mathrm{mg}\right)$ with a mean $\mathrm{LW}$ value of $2.2 \pm 1.472 \mathrm{mg}$ (Figure $8 \mathrm{~A}$ ) on one hand, and the rest of the population $\left(L_{\mathrm{P}}, \mathrm{n}=187\right)$ in which two cohorts were evident: from $10 \mathrm{mg}$ to $175 \mathrm{mg}$ (Mean = 79.157; SD = 44.93) and from $175 \mathrm{mg}$ to $570 \mathrm{mg}$ (Mean $=316.663 ; \mathrm{SD}=88.584)$. $\mathrm{A}$ low proportion of the population $(5.88 \%, \mathrm{n}=11)$ exceeding $600 \mathrm{mg}$ is not shown in Figure $8 \mathrm{~B}$. 
Table 4. Coefficients of Log-Log regression equations of Photogrammetric Surface $\left(P S=m^{2}\right)$ vs. Live Weight $(\mathrm{LW}=\mathrm{mg})$ of Eisenia andrei. Differences in individual equations for photogrammetric measurements of body surface in different positions are analyzed through ANCOVA

\begin{tabular}{|c|c|c|c|c|c|c|c|}
\hline Method & Position & $\mathbf{N}$ & LW (mg) & Volume $\left(\mathrm{mm}^{3}\right)$ & $\mathbf{R}^{2}$ & Intercept $\left(\mathrm{Cl}_{95 \%}\right)$ & Slope $\left(\mathrm{Cl}_{95 \%}\right)$ \\
\hline \multirow{3}{*}{ SEP } & Fully extended & 27 & $10.1-334.7$ & $12.4-160.6$ & 0.978 & $0.463 \pm 0.092$ & $0.682 \pm 0.041$ \\
\hline & Coiled & 41 & $10.1-334.7$ & $12.6-156.5$ & 0.989 & $0.459 \pm 0.048$ & $0.638 \pm 0.023$ \\
\hline & Intermediate & 78 & $10.1-334.7$ & $12.5-155.4$ & 0.984 & $0.481 \pm 0.040$ & $0.671 \pm 0.020$ \\
\hline \multirow{3}{*}{ SP } & Fully extended & 52 & $10.1-405.8$ & $12.4-197.0$ & 0.980 & $0.501 \pm 0.059$ & $0.672 \pm 0.027$ \\
\hline & Coiled & 138 & $10.1-445.0$ & $12.6-196.7$ & 0.984 & $0.512 \pm 0.030$ & $0.666 \pm 0.014$ \\
\hline & Intermediate & 371 & $10.1-461.9$ & $12.5-200.3$ & 0.980 & $0.485 \pm 0.022$ & $0.678 \pm 0.010$ \\
\hline Method & ANCOVA & DF & $F$-Value & $P$-value & Common Values & & \\
\hline \multirow{2}{*}{ SEP } & Slope & 2,140 & 0.314 & 0.7312 No. Sig & $0.676 \pm 0.014$ & & \\
\hline & Intercept & 2,142 & 0.081 & 0.9224 No. Sig & $0.472 \pm 0.029$ & & \\
\hline \multirow{2}{*}{ SP } & Slope & 2,555 & 0.76 & 0.4684 No. Sig & $0.674 \pm 0.007$ & & \\
\hline & Intercept & 2,557 & 0.322 & 0.7250 No. Sig & $0.494 \pm 0.017$ & & \\
\hline
\end{tabular}

LW = Live weight; PS = Photographic Surface; SEP = Single worm exhibiting every position; SP = Spontaneous Position; $\mathrm{DF}=$ Degrees of freedom; $\mathrm{Cl}_{95 \%}=$ Confidence intervals.

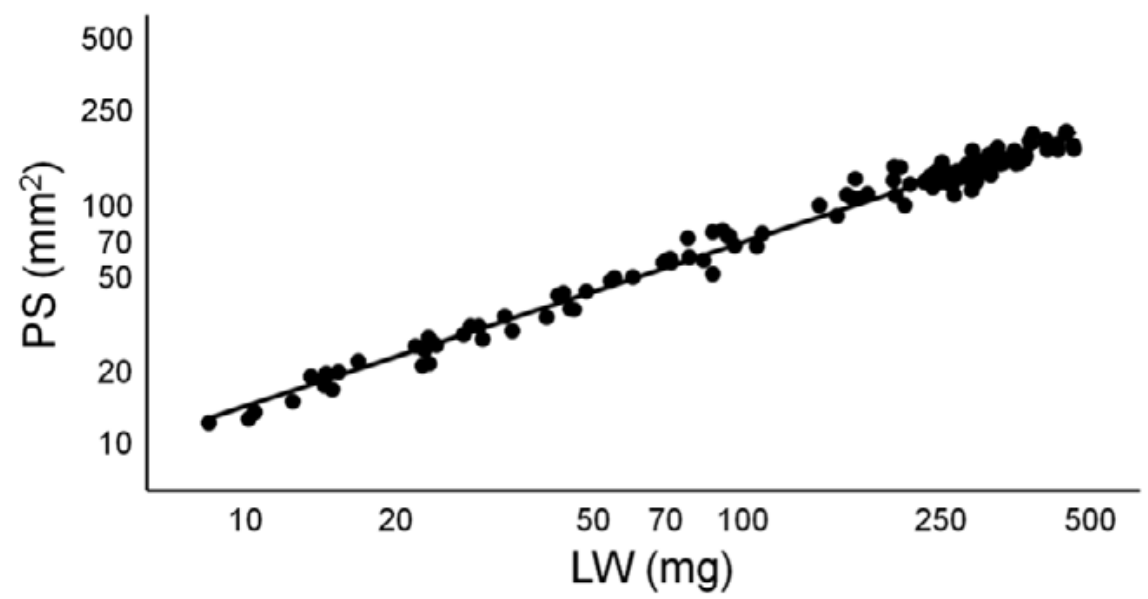

Figure 7. Photographic Surface $\left(P S=\mathrm{mm}^{2}\right)$ vs. Live Weight $(\mathrm{LW}=\mathrm{mg})$ in Eisenia andrei obtained using the Field Method: $P S=2.924^{*} L W^{0.689}\left(R^{2}=0.9849 ; n=123\right) . C l_{95 \%}$ is \pm 0.015 for the slope and \pm 0.22 for the elevation.

\subsection{Influence of feeding conditions}

Evaluation of the effects that different amounts of food being processed inside the digestive tube could have on the actual proportion of portrayed surface was undertaken standardizing 3 feeding conditions: Fed, 24 and 48 h fasting respectively.
As shown in Table 5, a common relationship between image surface estimations $\left(\mathrm{PS}=\mathrm{mm}^{2}\right)$ and $\mathrm{LW}(\mathrm{mg})$ was obtained irrespective of the length of starvation explaining $98 \%$ of experimental variation: $P S=4.623^{*} L^{0.647}$. 
(a)

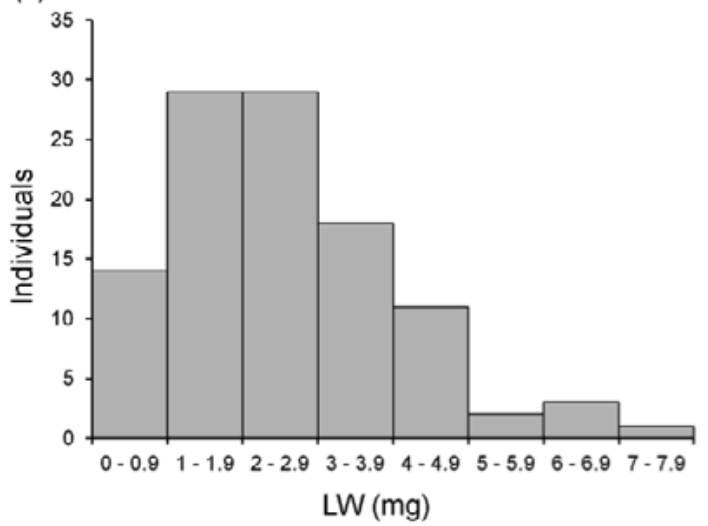

(b)

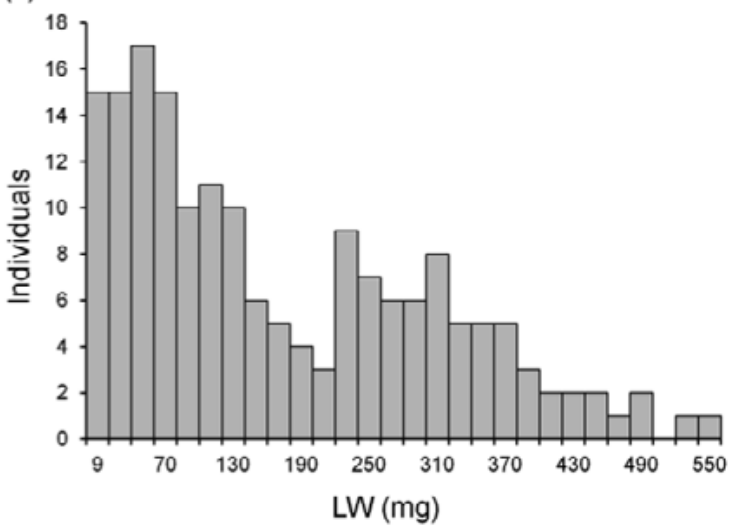

Figure 8. Histograms for the frequency distributions of Live Weight (LW = mg) of specimens of Eisenia andrei used in the Laboratory Method. a): Newly Hatched specimens $<8 \mathrm{mg}$ ( Mean $=2.2 \pm 1.472$ ). b): Population with sizes ranging from 10 $\mathrm{mg}$ to $3132 \mathrm{mg}$. Individuals larger than $570 \mathrm{mg}(\mathrm{n}=11 ; 5.88 \%)$ do not appear in the figure.

Table 5. Coefficients of Log-Log regression equations of Photogrammetric Surface $\left(P S=m^{2}\right)$ vs. Live Weight $(\mathrm{LW}=\mathrm{mg})$ of Eisenia andrei for different feeding conditions. Differences in individual equation for photogrammetric measurements of body surface between two different feeding conditions (Common Fasted \& Fed) analyzed through ANCOVA

\begin{tabular}{|c|c|c|c|c|c|c|c|}
\hline Feeding conditions & $\mathbf{N}$ & & ng) & PS $\left(\mathrm{mm}^{2}\right)$ & \multicolumn{2}{|c|}{ Intercept $\left(\mathrm{Cl}_{95 \%}\right)$} & Slope $\left(\mathrm{Cl}_{95 \%}\right)$ \\
\hline Fasted 24 h & 38 & & 31.8 & $26.9-289.2$ & \multicolumn{2}{|c|}{$0.657 \pm 0.065$} & $0.644 \pm 0.030$ \\
\hline Fasted $48 \mathrm{~h}$ & 38 & & 31.8 & $25.5-299.9$ & \multicolumn{2}{|c|}{$0.669 \pm 0.072$} & $0.653 \pm 0.033$ \\
\hline Fed & 187 & 10 & 132.0 & $12.5-778.2$ & \multicolumn{2}{|c|}{$0.574 \pm 0.035$} & $0.663 \pm 0.015$ \\
\hline \multirow[t]{4}{*}{ Fasted 24h Vs. 48h } & ANC & VA & DF & F-Value & $P$-Value & \multicolumn{2}{|c|}{ Common Value } \\
\hline & \multicolumn{2}{|c|}{ Slope } & 1,72 & 0.186 & 0.6676 No. Sig & \multicolumn{2}{|c|}{$0.647 \pm 0.023$} \\
\hline & \multicolumn{2}{|c|}{ TUCKEY } & DF & $\mathbf{q}$ & Significance & \multicolumn{2}{|c|}{ Common Value } \\
\hline & \multicolumn{2}{|c|}{ Intercept } & 72 & 0.76615 & No .Sig & \multicolumn{2}{|c|}{$0.665 \pm 0.052$} \\
\hline \multirow[t]{5}{*}{ Fed Vs. Fasted } & \multicolumn{2}{|c|}{ ANCOVA } & DF & F-Value & $P$-Value & \multicolumn{2}{|c|}{ Common value } \\
\hline & \multicolumn{2}{|c|}{ Slope } & 1,259 & 0.961 & 0.3279 No. Sig & \multicolumn{2}{|c|}{0.660} \\
\hline & \multicolumn{2}{|c|}{ Intercept } & 1,260 & 68.036 & $<0.0001$ Sig & & \\
\hline & & & & & Fasted & \multicolumn{2}{|c|}{0.638} \\
\hline & & & & & Fed & \multicolumn{2}{|c|}{0.582} \\
\hline
\end{tabular}

LW = Live weight; PS = Photographic surface DF = Degrees of freedom; CI95\%= Confidence intervals. 
Fasted individuals showed significant differences with the fed group regarding elevation 0.638 vs. 0.582 with a common slope of 0.660 :

\begin{tabular}{|l|l|}
\hline (F 3) & Fasted: $P S=4.34^{*} L W^{0.66}$ \\
\hline (F 4) & Fed: $P S=3.819^{*} L W^{0.66}$ \\
\hline
\end{tabular}

Unfed animals visible surface increases by a factor of 1.136 .

3.7. Photographic Surface and live weight relationship in Lab Method

Two significantly different regression equations were obtained for the LM in newly hatched worms $\left(L M_{\mathrm{NH}}: P S=4.11^{*} L W^{0.715}\right)$ and the remaining population $\left(L M_{P}: P S=3.75^{\star} L W^{0.663}\right)$, explaining
$86 \%$ and $97 \%$ of variability respectively (Table $6)$.

Analysis of this result will be undertaken next in connection with comparison between methods.

\subsection{Field vs. Laboratory method}

Linear regression analysis of the relationship between PS $\left(\mathrm{mm}^{2}\right)$ and LW $(\mathrm{mg})$ in the different groups of individuals used along the experiments are summarized in Table 6.

All equations were significant and regarding the regression coefficient, slight differences appeared when extreme disparity in size range applies: $\mathrm{LM}_{\mathrm{NH}}$ vs. $\mathrm{LM}_{\mathrm{P}}$ or $\mathrm{FM}$. Examination of confidence intervals revealed that a common significant function could be established for $L_{P}$ and $\mathrm{FM}\left(P S=3.27^{*} L W^{0.681} ; \mathrm{R}^{2}=0.97\right)$ indicating that resolution was similar for both methods.

Table 6. Coefficients of Log-Log regression equations of Photogrammetric Surface $\left(P S=m^{2}\right)$ vs.

Live Weight $(\mathrm{LW}=\mathrm{mg})$ of Eisenia andrei for different methods. Differences in individual equation for photogrammetric measurements of body surface between two groups of sizes (Common FM+LM \& $_{\mathrm{P}} \mathrm{LM}_{\mathrm{NH}}$ ) analyzed through ANCOVA

\begin{tabular}{|c|c|c|c|c|c|c|c|}
\hline Method & $\mathbf{N}$ & LW (mg) & PS $\left(\mathrm{mm}^{2}\right)$ & $\mathbf{R}^{2}$ & Intercept $\left(\mathrm{Cl}_{95 \%}\right)$ & Slope & Slope $\left(\mathrm{Cl}_{95 \%}\right)$ \\
\hline $\mathrm{LM}_{\mathrm{NH}}$ & 107 & $0.2-7.0$ & $1.2-2.0$ & 0.865 & $0.614 \pm 0.024$ & 0.715 & $0.661-0.769$ \\
\hline LM $_{P}$ & 187 & $10.1-3132.0$ & $12.5-778.2$ & 0.974 & $0.574 \pm 0.035$ & 0.663 & $0.648-0.679$ \\
\hline FM & 123 & $8.4-463.5$ & $12.17-175.6$ & 0.985 & $0.466 \pm 0.033$ & 0.689 & $0.674-0.704$ \\
\hline Common $\left(F M+L_{p}\right)$ & 310 & $8.4-3132.0$ & $12.17-778.2$ & 0.972 & $0.524 \pm 0.028$ & 0.677 & $0.664-0.690$ \\
\hline \multirow[t]{5}{*}{$F M+L_{P}$ vs. $L_{N H}$} & ANCOVA & DF & F-Value & $P$-Value & Common values & & \\
\hline & Slope & 1,413 & 2.973 & 0.0850 No. Sig & 0.681 & & \\
\hline & Intercept & 1,414 & 57.366 & $<0.0001$. Sig & & & \\
\hline & & & & $\mathrm{LM}_{\mathrm{NH}}$ & 0.625 & & \\
\hline & & & & $F M+L_{P}$ & 0.515 & & \\
\hline
\end{tabular}

LW = Live weight; PS = Photographic surface; LM $_{\mathrm{NH}}=$ Laboratory Method Newly Hatched; LM $=$ Laboratory Method.

Population over $8 \mathrm{mg}$ Live Weight; $\mathrm{FM}=$ Field method; $\mathrm{DF}=$ degrees of freedom; $\mathrm{Cl}_{95 \%}=$ Confidence intervals. 
Contrasting this common equation for larger animals with $\mathrm{LM}_{\mathrm{NH}}$ showed that the regression coefficient would be comparable (mean slope of 0.681) whereas the intercepts remained significantly different, increasing the body surface pictured by a factor of 1.29 in smaller animals $\left(P S=4.21^{*} L W^{0.681} ; R^{2}=0.865\right)$. This finding appears to be related to the results obtained for fed and fasted worms and the same considerations would be appropriate.

\section{Discussion}

Our breeding routine of Eisenia andrei fed on horse manure corresponds to optimal conditions (Domínguez and Edwards 2011) and characteristics of our ongoing culture are similar to those reported in the literature regarding minimum and maximum sizes attained for laboratory cultures grown in cow manure: between 6.5 to $1000 \mathrm{mg}$ live weight (Domínguez et al. 1997; Domínguez et al. 2000 for E. andrei and Gunadi et al. 2002 for E. foetida). Data from newly hatched organisms is not so frequent ranging from 6.5 to $11 \mathrm{mg}$ live weight for $E$. andrei and E. foetida (Savigny 1826) and our lower limit is the lowest in the literature: $0.2 \mathrm{mg}$ live weight with a size distribution reaching $7 \mathrm{mg}$ for worms born within $24 \mathrm{~h}$ surveying. This aspect is of considerable interest since the work pays special attention to growth patterns during the earliest stages of life cycle and focuses on providing a simple and reliable tool to perform long term individual growth studies.

4.1. Live weight measurements: body water, gut content $\&$ biomass assessment

Lowe and Butt (2005) and more recently Fründ et al. (2010) have reviewed in detail the relationships between moisture content of soil and physiological status of earthworms, strongly connected to hydration level of tissues. In this work, soil moisture under culture conditions was kept constant $(80 \% \mathrm{RH})$ precluding changes in water potential that could alter tissue hydration hindering biomass inference from live weight determinations: Kretzschmar and Bruchou (1991) report significant live weight losses up to $60 \%$ of initial weight associated with decreasing humidity that were still compatible with activity. More recently Stovold et al. (2003) demonstrated that this water loss resides basically in the middle and end segments of Aporrectodea caliginosa (Savigny 1826), allowing maintenance of radial pressure on the anterior end and concomitantly burrowing activity.

Our data for $E$. andrei obtained over a wide size range (1.7 to $648.6 \mathrm{mg}$ live weight) indicates that water content relates isometrically to body weight, reaching $90 \%$ in fed worms and decreasing to $84 \%$ after a period of $48 \mathrm{~h}$ starvation. These figures, obtained through equations explaining over $99 \%$ of the variability, relate well to general results for lumbricids (Laverack 1963; Florkin 2012) and coincide with earlier data of $83.3 \%$ for E. foetida reported by O'Brien (1957a, 1957b). Water losses associated with gut voidance have been reported by Martin (1986) for three species of pasture Lumbricidae. Furthermore, our results show that gut content removal after $48 \mathrm{~h}$ fasting implies $13.32 \%$ weight loss, in agreement with data for Lumbricus terrestris (Linnaeus 1758) obtained for an identical starvation period by Eisenhauer et al. (2009) appearing in Eisenia andrei as size-independent. Intestine voidance took place primarily in the initial $24 \mathrm{~h}$, accounting for $90.41 \%$ of total faeces production in accordance with Martin (1986) and egestion dynamics reported by Dalby et al. (1996) for various species of Aporrectodea with size ranges included in our study.

4.2. Morphometrical determinations of biomass: Length, diameter and volume

Length scales allometrically to live weight and a weight exponent of 0.6683 indicates growth involves volume gain (i.e. live weight) that exceeds, in relative terms, length augmentation. Consequently, the Surface to Volume ratio becomes increasingly reduced according to a weight exponent of -0.32 . Mean body 
diameter scales to the live weight isometrically: the weight exponent is 0.3352 according to theoretical predictions for linear dimensions $(b=0.333)$. Simultaneous consideration of weight exponents exhibited by length and diameter derives in relatively thinner specimen in the course of development. Kurtz and Kier (2014) have recently reported analogous results for $L$. terrestris in the comparison of juveniles (1-3 g live weight) with fully grown adults (3-10 g) with both weight exponents departing from isometry which, in terms of the Length/ Diameter ratio represents a $128 \%$ to $163 \%$ increase. In E. andrei a sharp difference appears between juveniles (mean live weight $43.8 \mathrm{mg}$ ) and sub-adults and mature specimen (mean live weight $308.6 \mathrm{mg}$ ): Length/Diameter evolves from 3.67 to 21.45 respectively and reaching a body length of $34 \mathrm{~mm}$ implies reducing diameter to $\sim 1 / 3$.

Two alternative approaches to volume determination, geometric calculations from calliper measurements and water displacement by immersion have produced identical results regarding relation with live weight: isometric relation with elevation value of 0 . Hence, volumetric estimations can be directly derived from live weight measurements.

\subsection{Surface evaluation through image analysis}

Frequent handling of organisms may lead to damage and variable water loss rendering direct measurements of live wet weight unreliable as a parameter with which to estimate biomass and follow growth with time. In fact, procedures involved in picture-taking proved less time consuming (a factor of 3 per worm) than safe manipulation of worms undertaken to obtain accurate gravimetric determinations of live weight or linear parameters while establishing the reference scaling of dry biomass to live weight. Nevertheless extreme care while dealing with animals resulted in exponential functions with $\mathrm{R}^{2}>99 \%$ for both fed and fasted (48 h) organisms.

Since determining the minimum number of pictures needed to provide repeatable and reliable estimations of size as well as deciding on the body position most suitable to those purposes was essential, initial design took into consideration body shape and a good number of pictures were taken per individual. In fact, the shape adopted by the animals on the Petri dish (always with the ventral side down) had no effect on accuracy in terms of the linear regression equations relating area $\left(\mathrm{mm}^{2}\right)$ to live weight (mg) and a common function explaining $98 \%$ of variation was calculated. Regression equations relating area determined through image analysis to dry weight have been used in pond macroinvertebrates ranging from 0.01 to $77 \mathrm{mg}$ dry weight (Bernardini et al. 2000), where worm-shaped Dugesia presented a size range in coincidence with our newly hatched Eisenia andrei (0.02 mg dry weight). In their work, area appeared as the best predictor of biomass against other parameters (perimeter, axis), showing higher values for the correlation coefficient for every species, especially for smaller organisms. Regarding the required number of pictures to be processed, no differences in precision were found in a range of 2 to 10 pictures inspected. The variation coefficient remained $6 \%$ irrespective of size: worms are small (mean diameter $2.98 \mathrm{~mm} \pm 0.7979)$ and as related to fixed focal distance $(25 \mathrm{~cm})$ minimum and maximum diameters represent $0.2 \%$ and $2 \%$ respectively. Under these conditions, the photogrammetric surface represents $34.04 \%$ of the geometric surface $\left(R^{2}=96 \%\right)$. Comparable studies have been performed in sponges, where the numbers of pictures inspected involved 2 (Page et al. 2005), 3 (Koopmans and Wijffels 2008) or 5 (Abdo et al. 2006) considering the bewildering display of morphologies and the underwater picture constraints. Perea et al. (2008), working with juvenile land snails (Cantareus aspersus) of similar size range to the Eisenia andrei used in our experiment, examined 3 to 5 images. Two replicates appeared thus appropriate for E. andrei considering their consistent cylindrical shape, in coincidence with Vanaverbeke et al. (2003) who analyzed nematode biomass in sand bank marine communities in terms of 2-3 replicates.

4.4. Surface determinations and feeding conditions

Starvation (24 to $48 \mathrm{~h}$ ) implies a reduction of $13.32 \%$ in live weight irrespective of body size 
which does not influence weight exponent and both fed and fasted worms present a common slope of 0.66 . The elevation, however, increases from 3.82 in fed animals to 4.34 in starved specimens. Since water acts as a hydrostatic skeleton in worms, water loss derived from starvation implies loss of turgidity and flattening and, consequently, a larger proportion of surface exposure to the camera lens (a factor of 1.136). This conclusion implies that differences in the feeding condition of worms from currently feeding to complete gut voidance would require the alternative use of the above-mentioned equations or a combination of the two if variability in foraging behaviour is suspected. Nevertheless, in the context of our study, rearing conditions correspond to optimal (Domínguez and Edwards 2011) and the population would have probably reached a dynamic steady state in which animals are presumably actively feeding.

\subsection{Surface determination and size: Laboratory vs. field method}

No differences between laboratory and field methods appear when size exceeds $8 \mathrm{mg}$ live weight, resulting in a common linear function relating area to live weight, with a weight exponent of 0.681 and an elevation of 3.27. Below $8 \mathrm{mg}$ weight, the exponent remains unchanged but the value for the elevation increases to 4.21 (factor increase 1.287). In this respect, surface to volume ratio increases in a continuum towards lower sizes i.e. the hydrostatic skeleton $\left(\mathrm{mm}^{3}\right)$ per unit area $\left(\mathrm{mm}^{2}\right)$ decreases in smaller worms: for Eisenia Andrei of $10 \mathrm{mg}$ live weight surface to volume ratio is 0.21 and reaches 0.70 for $400 \mathrm{mg}$ organisms. Thus some size dependant flattening occurs, becoming significant below $8 \mathrm{mg}$ live weight. Although biomass predictions are similar with the two methods (over $8 \mathrm{mg}$ live weight), the laboratory method allows direct estimations of surface and is less time consuming than the field method where image analysis requires Photoshop processing.

\section{Conclusions}

The main point has been demonstrating that images taken without special requirements can be a good tool to assess biomass of softbodied tubular organisms within a wide size range (starting on eight $\mathrm{mg}$ live weight for the field method) and this regardless of shape (body position) and number of pictures taken. Water loss derived from starvation implies a loss of turgidity and flattening and, consequently, a larger proportion of surface exposure to the camera lens (a factor of 1.136). These characteristics imply the procedure can be applied to field surveys of growth and biomass estimations from earlier life stages since pictures of worms would be reliably related to their body mass. Scaling of weight to portrayed surface should be established for the particular occasion (around 20 to 30 individuals for a regression analysis). These practices minimize capture and sacrifice of animals associated with laboratory determinations, providing a permanent record that can be reviewed for posterior analysis.

\section{Acknowledgements}

This work has been partially covered by Basque Government Grants to Esther IparraguirreBolaños and Carlos Brea-San Nicolás. 


\section{REFERENCES}

- Abdo DA, Seager JW, Harvey ES, McDonald JI, Kendrick GA, Shortis MR. 2006. Efficiently measuring complex sessile epibenthic organisms using a novel photogrammetric technique. J Exp Mar Biol Ecol. 339(1):120-133.

- Bernardini V, Solimini AG , Carchini G. 2000. Application of an image analysis system to the determination of biomass (ash free dry weight) of pond macroinvertebrates. Hydrobiologia 439(1):179-182.

- Dalby PR, Baker GH, Smith SE. 1996. "Filter paper method" to remove soil from earthworm intestines and to standardise the water content of earthworm tissue. Soil Biol Biochem. 28(4):685-668.

- Domínguez J, Briones MJI, Mato S. 1997. Effect of the diet on growth and reproduction of Eisenia andrei (Oligochaeta, Lumbricidae). Pedobiologia 4(6):566-576.

- Domínguez J, Edwards CA. 2011. Biology and Ecology of earthworm species used for vermicomposting. In: Edwards CA, Arancon NQ, Sherman RL, editors. Vermiculture Technology: Earthworms, organic wastes and environmental management. London: CRC Press, Taylor \& Francis Group. p. 27-40.

- Domínguez J, Edwards CA, Webster M. 2000. Vermicomposting of sewage sludge: Effect of bulking materials on the growth and reproduction of the earthworm Eisenia andrei. Pedobiologia 44(1):24-32.

- Eisenhauer N, Schuy M, Butenschoen O, Scheu S. 2009. Direct and indirect effects of endogeic earthworms on plant seeds. Pedobiologia 52(3):151-162.

- Florkin M. 2012. Chemical Zoology V4: Annelida, Echiuria, And Sipuncula. New York: Academic Press Inc.

- Fründ HC, Butt K, Capowiez Y, Eisenhauer N, Emmerling C, Ernst G, Potthoff M, Schädle M, Schrader S. 2010. Using earthworms as model organisms in the laboratory: recommendations for experimental implementations. Pedobiologia 53(2):119-125.

- Gunadi B, Blount C, Edwards CA. 2002. The growth and fecundity of Eisenia fetida (Savigny) in cattle solids precomposted for different periods. Pedobiologia 46(1):1523.

- Koopmans M, Wijffels RH. 2008. Seasonal growth of the sponge Haliclona oculata (Demospongiae, Haplosclerida). Mar Biotechnol. 10(5):502-510.

- Kretzschmar A, Bruchou C. 1991. Weight response to the soil water potential of the earthworm Aporrectodea longa. Bio Fert Soils. 12(3):209-212.

- Kurtz JA, Kier WM. 2014. Scaling of the hydrostatic skeleton in the earthworm Lumbricus terrestris. J Exp Biol. 217(11):1860-1867.
- Laverack MS. 1963. International series of monographs on pure and applied biology, zoology V15: The physiology of earthworms. New York: Pergamon Press Ltd.

- Littler MM, Little DS. 1985. Non-destructive sampling. In: Littler MM, Littler DS, editors. Handbook of Phycological Methods: Ecological field Methods: Macroalgae. Cambridge: Cambridge University Press. p. 161-175.

- Lowe CN, Butt KR. 2005. Culture techniques fort soil dwelling earthworms: A review. Pedobiologia 49(5):401413.

- Martin N. 1986. Earthworm biomass: influence of gut content and formaldehyde preservation on live-todry weight ratios of three common species of pasture Lumbricidae. Soil Biol Biochem. 18(3):245-250.

- O'Brien BR. 1957a. Evidence in support of an axial metabolic gradient in the earthworm. Aust J Exp Biol Med. 35(1):83-9.

- O'Brien BR. 1957b. Tissue metabolism during posterior regeneration in the earthworm. Aust $\mathrm{J}$ Exp Biol Med. 35(4):373-380.

- Page MJ, Northcote PT, Webb VL, Mackey S, Handley SJ. 2005. Aquaculture trials for the production of biologically active metabolites in the New Zealand sponge Mycale hentscheli. Aquaculture 250(1):256-269.

- Perea J, García A, Acero R, Valerio D, Gómez G. 2008. A photogrammetric methodology for size measurements: application to the study of weight-shell diameter relationship in juvenile Cantareus aspersus snails. J Mollus Stud. 74(3):209-2013.

- Ponder W, Hutchings P, Chapman R. 2002. Overview of the conservation of Australian marine invertebrates. A report for environment Australia. Australian Museum 6 College Street, Sydney, NSW 2010 Australia. 588 p.

- Stovold RJ, Whalley WR, Harris PJ. 2003. Dehydration does not affect the radial pressures produced by the earthworm Aporrectodea caliginosa. Biol Fert Soils. 37(1):23-28.

- Vanaverbeke J, Steyaert M, Vanreusel A, Vincx M. 2003. Nematode biomass spectra as descriptors of functional changes due to human and natural impact. Mar Ecol Prog Ser. 249:157-170. 